\title{
Benzotriazole derivatives palladium complex: Synthesis, characterization, antifungal and catalytic activity
}

\author{
Complejos de paladio y derivados de benzotriazol: Síntesis, caracterización, \\ actividad antifúngica y catalítica
}

\author{
C. Vesga-Hernández (iD , G. P. De-la-Vega-Quintero iD ; E. Galarza-De-Becerra iD , J. Patiño- \\ Rivera ; A. Francisco-De-la-Parra iD
}

\begin{abstract}
Two new palladium benzotriazole complexes (7) and (8) was synthetized from [PdCl2(NCCH3)2] (6) and the benzotriazole derivatives 1,3-phenylenebis-( 1 H-benzotriazol-1yl)methanone) (3) and 1,3-bis(1H-benzotriazol-1-ylmethyl)benzene (5). Its antifungal and Mizoroki-Heck catalytic preliminar activity was evaluated, finding that the palladium complexes are more effective than the ligands against Aspergillus niger and the turn over number (TON) for the complexes 7 and 8 was 221 and 219, which are under the average for similar complex reported on literature.
\end{abstract}

Index Terms - Antifungal activity, benzotriazole derivatives, Mizoroki-Heck reaction, palladium complexes.

Resumen- Se sintetizaron dos nuevos complejos de paladiobenzotriazol (7) y (8), a partir de los ligandos 1,3-fenilen-((1Hbenzotriazol-1-il)metanona) (3) y 1,3-bis(1H-benzotriazol-1-ilmetil)benceno (5). Su actividad antifúngica y catalítica en la reacción de Mizoroki-Heck fue evaluada preliminarmente, encontrándose que los complejos de paladio son más efectivos que los ligandos libres contra el hongo Aspergillus niger y que el número de recambio (TON) para los complejos 7 y 8 fue de 221 y 219, respectivamente, el cual está por debajo del promedio encontrado en la literatura para este tipo de complejos.

Palabras claves - Actividad antifúngica, benzotriazol, complejos de paladio, reacción Mizoroki-Heck.

\section{INTRODUCTION}

A ZOLE ligands have shown a good biological activity, which is potentiated by forming complexes with transition metals [1-2]. They are compounds with intermediate basic character in the model of acid and hard soft bases, which facilitates that, could be unite to metals that are intermediate

This manuscript was sent on November 30, 2018 and accepted on March 28, 2019.This work was supported by the Universidad del Valle.

C. Vesga-Hernández is with the Universidad del Atlántico (e-mail: cvesgah@mail.uniatlantico.edu.co).

G. P. De-la-Vega-Quintero is with the Universidad del Valle (e-mail: gala.delavega@correounivalle.edu.co). acids like $\mathrm{Cu}$ (II), $\mathrm{Ni}$ (II) or $\mathrm{Zn}$ (II), consequently these intermediate acid-base pairs form favorable bonds [3]. Imidazole is considered an intermedia base, because is a $\sigma$ moderate donor and a weak $\pi$ acceptor, with a $\sigma$ donor and $\pi$ acceptor character between that found for saturated amines as ammonia $\left(\mathrm{NH}_{3}\right)$ and unsaturated amines as pyridine [4], imidazole is located above oxygen based donors and under ammonia and pyridine in the spectrochemical series.

Triazoles are more basic ligands than the respective imidazoles, with a greater $\pi$-acceptor interaction and a weak $\sigma$-donation (less basic than imidazoles [5]. For azoles, the series in which the basicity- $\sigma$ increases and the acidity- $\pi$ decreases follows the order: 1,2,4-triazole> pyrazole > thiazole > imidazole. Consequently, the triazole ligands are better for stabilizing softer metals [6].

Due to ergosterol constitutes a fundamental component of fungal membranes, many antifungal medications have been develop to inhibit the enzymes involved in its production such as $14 \alpha$ demethylase (CYP51). Azole antifungals are potent inhibitors of fungal lanosterol and have been use for eradication of systemic candidiasis clinically [7].

In our research work, we study here the complexes of palladium (II) with the ligands benzotriazole derivate. The antifungal activities of the ligand and its complexes were done. Moreover, the activity catalytic of complexes has been studied.

E. Galarza-De-Becerra is with the Universidad del Valle sede Yumbo (email: alvaro.delaparra@correounivalle.edu.co).

Álvaro Francisco De la Parra Morales is with the Universidad del Valle (email: alvaro.delaparra@correounivalle.edu.co).

Julián Patiño Rivera is with the Universidad del Valle sede Yumbo (e-mail: julian.patino@correounivalle.edu.co). 


\section{EXPERIMENTAL}

\section{A. General}

All reagents were purchased from best-known commercial sources and were used without any further purification. Solvents was dried and purified. Fourier transform infrared (FT-IR) spectrum of the synthesized compounds was collected with a SHIMADZU-8400/8900 and NICOLET - 6700 spectrophotometers for 400 a $4000 \mathrm{~cm}^{-1}$ and $4000-225 \mathrm{~cm}^{-1}$ respectively, with samples and $\mathrm{KBr}$ pressed to form tablets. The ${ }^{1} \mathrm{H}$ and ${ }^{13} \mathrm{C}$ Nuclear Magnetic Resonance (NMR) spectra were recorded with a BRUCKER DPX UltraShield Advance II spectrometer operating at $400 \mathrm{MHz}$, using $\mathrm{CDCl}_{3}$ or DMSO as solvent and tetramethylsilane (TMS) as internal standard. All chemical shifts were report in parts per million ( $\mathrm{ppm}$ ) relative to TMS. Mass spectra were record on a SHIMADZU-GC-MSQP2010 spectrometer by technique electron ionization operating at $70 \mathrm{eV}$. Thin layer chromatography (TLC) was performed on a $0.2-\mathrm{mm}$ pre-coated plates of silica gel F254 (Merck). The elemental analyses were obtain using an Elemental Analyzer Finnigan Flash EA1112 CHN.

\section{B. Chemistry}

1. Procedure for synthesis of ligands

1,3-phenylenebis((1H-benzotriazol-1-yl)methanone), (3): A mixture from toluene $5 \mathrm{~mL}$, benzotriazole, $1(586.8 \mathrm{mg} ; 4.9$ mmol) and triethylamine $\left(\mathrm{Et}_{3} \mathrm{~N}, 1.5 \mathrm{~mL}\right)$ was heat to $130{ }^{\circ} \mathrm{C}$, during 30 minutes. The solution was add to isophthaloyl dichloride, 2, (500 $\mathrm{mg} ; 2.5 \mathrm{mmol})$ in toluene $(10 \mathrm{~mL})$; the reaction mixture, had been refluxing for $72 \mathrm{~h}$ with constant stirring, under an inert atmosphere of nitrogen. The reaction progress was monitor by TLC. After, solvent was eliminate under reduced pressure and the solid obtained was dissolve in chloroform $\left(\mathrm{CHCl}_{3}\right)$ and washed with saturated aqueous $\mathrm{NaCl}$ solution (3 times x $15 \mathrm{~mL}$ ). The organic layer was dry over anhydrous magnesium sulfate $\left(\mathrm{MgSO}_{4}\right)$ and concentrate. The residue was precipitate in ethyl ether, obtaining $381.2 \mathrm{mg}$ white powder. (Yield: $41.78 \%$ ). Ligand 3 is soluble in polar solvents.

1,3-bis(1H-benzotriazol-1-ylmethyl)benzene, (5): A mixture benzotriazole, $\mathbf{1},(676.6 \mathrm{mg} ; 5.7 \mathrm{mmol})$ in toluene $(5$ $\mathrm{mL})$ and triethylamine $(1.5 \mathrm{~mL} ; 1.09 \mathrm{mmol})$ was heated to 130 ${ }^{\circ} \mathrm{C}$ by 30 minutes constant stirring. The solution was added to 1,3-(bischloromethyl)benzene, 4, (500 mg; $2.4 \mathrm{mmol}$ ) in toluene $(10 \mathrm{ml})$, that reaction mixture, was subjected to reflux for $72 \mathrm{~h}$ with constant stirring, under nitrogen atmosphere. The reaction progress was monitor by TLC. After, solvent was eliminate under reduced pressure and the solid obtained was dissolve in chloroform $\left(\mathrm{CHCl}_{3}\right)$ and washed with saturated aqueous $\mathrm{NaCl}$ solution ( 3 times $\times 15 \mathrm{~mL}$ ). The organic layer was dry over anhydrous magnesium sulfate $\left(\mathrm{MgSO}_{4}\right)$ and concentrate. The residue was precipitate in ethyl ether, obtaining $518.8 \mathrm{mg}$ white solid. (Yield: $53.08 \%$ ). Ligand $\mathbf{5}$ is soluble in common organic solvents.
2. Procedure for synthesis of complexes

Prior to assembly for metal-ligand coordination reactions, bis(acetonitrile)dichloropalladium (II), 6 , precursor used in the synthesis of complexes $\mathbf{7}$ and $\mathbf{8}$ was prepared. Starting with anhydrous palladium (II) chloride (500 mg; $2.8 \mathrm{mmol}$ ), $15 \mathrm{~mL}$ were added of dry acetonitrile, the mixture was refluxed for 5 hours under nitrogen atmosphere, obtaining (468.1 mg; 1.8 mmol) of palladium precursor, $\left[\mathrm{PdCl}_{2}\left(\mathrm{CH}_{3} \mathrm{CN}\right)_{2}\right], \mathbf{6}$.

[Pd(NN-(1,3-bis((1H-benzotriazol-1-yl)methanone)benzene))Cl ], (7): Ligand 3 (100 $\mathrm{mg} ; 0.27 \mathrm{mmol}$ ) was added in 10 $\mathrm{ml}$ of tetrahydrofuran (THF), while heating to $50^{\circ} \mathrm{C}$ until complete dissolution. An equimolar amount of $\left[\mathrm{PdCl}_{2}\left(\mathrm{CH}_{3} \mathrm{CN}\right)_{2}\right], 6,(70 \mathrm{mg} ; 0.27 \mathrm{mmol}) \mathrm{mix}$ to the ligand solution, and the reaction was refluxed for 16 hours with constant stirring. Resulting product was filtered and washed hot with $\mathrm{CH}_{2} \mathrm{Cl}_{2}$, acetone and ethyl ether, obtaining a brown solid, which was dried at $60^{\circ} \mathrm{C}$ and stored under vacuum $(55.5 \mathrm{mg}$, Yield: $36.32 \%$ ).

[Pd(NN-(1,3-bis((1H-benzotriazol-1-ylmethyl)benzene))Cl ], (8): Compound 5 (100 mg; 0.29 mmol) was dissolved in acetonitrile $(10 \mathrm{ml})$ and mixed with $(75.2 \mathrm{mg} ; 0.29 \mathrm{mmol})$ of $\left[\mathrm{PdCl}_{2}\left(\mathrm{CH}_{3} \mathrm{CN}\right)_{2}\right], 6$, the reaction was refluxed for 15 hours with constant stirring. The reaction progress was monitored by TLC. After, the mixture was filter, the solid obtained was wash with $\mathrm{CH}_{2} \mathrm{Cl}_{2}$, acetone and ethyl ether, obtaining a yellow-ocher solid, which was dried at $60^{\circ} \mathrm{C}$ and stored under vacuum. (127.6 mg, Yield: 85\%).

\section{Characterization of ligands and complexes}

1,3-phenylenebis((1H-benzotriazol-1-yl)methanone), (3): FT-IR (KBr, cm $\left.{ }^{-1}\right)$ : vCH-Ph 3082.25, vCO 1695.43, vC $=\mathrm{C}-\mathrm{C}$ 1487.12, vC-N 1450.47, vbenzotriazole 1039.63, vbenzotriazole 869.89; $\mathrm{NMR}{ }^{1} \mathrm{H}\left(400 \mathrm{MHz}, \mathrm{CDCl}_{3}, \mathrm{ppm}\right): 8.46$ $(\mathrm{d}, 2 \mathrm{H}, \mathrm{J}=8.2 \mathrm{~Hz}) \mathrm{H}_{10}, 8.21$ (d, $\left.2 \mathrm{H}, \mathrm{J}=8.2 \mathrm{~Hz}\right) \mathrm{H}_{7}, 7.86(\mathrm{t}, 1 \mathrm{H}$, $\mathrm{J}=7.9 \mathrm{~Hz}) \mathrm{H}_{1}, 7.61(\mathrm{t}, 2 \mathrm{H}, \mathrm{J}=7.8 \mathrm{~Hz}) \mathrm{H}_{9}, 7.78(\mathrm{t}, 2 \mathrm{H}, \mathrm{J}=7.7 \mathrm{~Hz})$ $\mathrm{H}_{8}, 8.59$ (d, 2H, J=8.2 Hz) $\mathrm{H}_{3}, 9.10(\mathrm{~s}, 1 \mathrm{H}) \mathrm{H}_{2} . \mathrm{NMR}{ }^{13} \mathrm{C}(100$ $\left.\mathrm{MHz}_{\mathrm{CDCl}}, \mathrm{ppm}\right): 165.56 \mathrm{C}_{5}, 145.85 \mathrm{C}_{11}, 132.22 \mathrm{C}_{4}, 132.05$ $\mathrm{C}_{6}, 135.02 \mathrm{C}_{2}, 136.25 \mathrm{C}_{3}, 130.75 \mathrm{C}_{7}, 128.76 \mathrm{C}_{8}, 126.67 \mathrm{C}_{9}$, $120.38 \mathrm{C}_{10}, 114.85 \mathrm{C}_{1}$; EI-MS (m/z): $368 \mathrm{M}^{+}, 222\left[\mathrm{M}^{+}-146\right]$ base peak.

1,3-bis(1H-benzotriazol-1-ylmethyl)benzene, (5): FT-IR $\left(\mathrm{KBr}, \mathrm{cm}^{-1}\right)$ : vCH-Ph 3057.17, $\mathrm{v}_{\mathrm{as}}-\mathrm{CH} 2$ 2980.02, vC $=\mathrm{C}-\mathrm{C}$ 1492.90, vC-N 1452.40, vbenzotriazole 1078.21, vbenzotriazole 902.69; $\mathrm{NMR}^{1} \mathrm{H}\left(400 \mathrm{MHz}, \mathrm{CD}_{3} \mathrm{COCD}_{3}\right.$, ppm): 8.03 (d, 2H) $\mathrm{H}_{10}, 7.62$ (d, 2H) $\mathrm{H}_{7}, 7.40$ (b.s., 1H) $\mathrm{H}_{1}, 7.43$ (b.d., 2H) $\mathrm{H}_{9}, 7.47$ (b.d., 2H) $\mathrm{H}_{8}, 7.37$ (d, 2H) $\mathrm{H}_{3}, 7.33$ (s, 1H) $\mathrm{H}_{2}$, $5.98(\mathrm{~s}, 4 \mathrm{H}) \mathrm{H}_{5}$. NMR ${ }^{13} \mathrm{C}\left(100 \mathrm{MHz}, \mathrm{CD}_{3} \mathrm{COCD}_{3}, \mathrm{ppm}\right): 51.16$ $\mathrm{C}_{5}, 146.14 \mathrm{C}_{11}, 136.75 \mathrm{C}_{4}, 132.90 \mathrm{C}_{6}, 129.44 \mathrm{C}_{2}, 127.23 \mathrm{C}_{3}$, 119.47 $\mathrm{C}_{7}, 123.74 \mathrm{C}_{8}, 127.60 \mathrm{C}_{9}, 110.19 \mathrm{C}_{10}, 126.32 \mathrm{C}_{1}$; EI MS (m/z): $340 \mathrm{M}^{+}, 207$ [M-132] base peak. 
[Pd(NN-(1,3-bis $((1 \mathrm{H}$-benzotriazol-1-yl)methanone)benzene)) $\mathrm{Cl}_{2}$ ], (7): $\mathrm{FT}-\mathrm{IR}\left(\mathrm{KBr}, \mathrm{cm}^{-1}\right)$ : vCO 1621.22, vC $=\mathrm{C}-\mathrm{C}$ 1489.42, vC-N 1447.26, vbenzotriazole 1025.84, vbenzotriazole 854.83 ; RMN ${ }^{1} \mathrm{H}\left(400 \mathrm{MHz}\right.$, DMSO $\left.\mathrm{d}_{6}, \mathrm{ppm}\right)$ : $8.38(\mathrm{~d}, 2 \mathrm{H}, \mathrm{J}=8.2 \mathrm{~Hz}) \mathrm{H}_{10}, 8.33(\mathrm{~d}, 2 \mathrm{H}, \mathrm{J}=8.2 \mathrm{~Hz}) \mathrm{H}_{7}, 7.95$ (t, $1 \mathrm{H}, \mathrm{J}=7.9 \mathrm{~Hz}) \mathrm{H}_{1}, 7.71(\mathrm{t}, 2 \mathrm{H}, \mathrm{J}=7.8 \mathrm{~Hz}) \mathrm{H}_{9}, 7.89(\mathrm{t}, 2 \mathrm{H}, \mathrm{J}=7.7$ $\mathrm{Hz}) \mathrm{H}_{8}, 8.50(\mathrm{~d}, 2 \mathrm{H}, \mathrm{J}=8.2 \mathrm{~Hz}) \mathrm{H}_{3}, 8.82(\mathrm{~s}, 1 \mathrm{H}) \mathrm{H}_{2} . \mathrm{NMR}^{13} \mathrm{C}$ $\left(100 \mathrm{MHz}, \mathrm{DMSO} \mathrm{d}_{6}, \mathrm{ppm}\right): 166.23 \mathrm{C}_{5}, 145.77 \mathrm{C}_{11}, 132.38 \mathrm{C}_{4}$, $132.19 \mathrm{C}_{6}, 134.18 \mathrm{C}_{2}, 136.36 \mathrm{C}_{3}, 131.44 \mathrm{C}_{7}, 127.34 \mathrm{C}_{8}, 124.89$ $\mathrm{C}_{9}, 120.63 \mathrm{C}_{10}, 115.01 \mathrm{C}_{1}$.

[Pd(NN-(1,3-bis((1H-benzotriazol-1-ylmethyl)benzene $))$ $\mathrm{Cl}_{2}$ ], (8): FT-IR $\left(\mathrm{KBr}, \mathrm{cm}^{-1}\right)$ : vCH-Ph 3062.96, vas- $\mathrm{CH}_{2}$ 2960.73, vC $=\mathrm{C}-\mathrm{C} 1492.90$, vC-N 1454.33, vbenzotriazole 1001.06, vbenzotriazole 950.91; NMR ${ }^{1} \mathrm{H}\left(400 \mathrm{MHz}\right.$, DMSO $\mathrm{d}_{6}$ ppm): 8.05 (d, 2H) $\mathrm{H}_{10}, 7.74$ (d, 2H) $\mathrm{H}_{7}, 7.40$ (t, 3H) $\mathrm{H}_{1}, 7.48$ (t, 2H) $\mathrm{H}_{9}, 7.40$ (t, 3H) $\mathrm{H}_{8}, 7.27(\mathrm{~d}, 2 \mathrm{H}) \mathrm{H}_{3}, 7.32$ (s, 1H) $\mathrm{H}_{2}$, 5.48 (s, 4H) $\mathrm{H}_{5}$. NMR ${ }^{13} \mathrm{C}(100 \mathrm{MHz}$, DMSO d 6 , ppm): 51.23 $\mathrm{C}_{5}, 145.76 \mathrm{C}_{11}, 136.95 \mathrm{C}_{4}, 133.08 \mathrm{C}_{6}, 129.86 \mathrm{C}_{2}, 127.93 \mathrm{C}_{3}$, $119.69 \mathrm{C}_{7}, 124.50 \mathrm{C}_{8}, 128.04 \mathrm{C}_{9}, 111.05 \mathrm{C}_{10}, 127.72 \mathrm{C}_{1}$.

\section{Preliminars}

1. Catalytic tests of compounds $\mathbf{7}$ and $\mathbf{8}$ in the MizorokiHeck reaction

The reaction was carried out using a two-neck balloon as a reaction vessel, into which was added a solution of the palladium catalyst in DMF (7: $0.8 \mathrm{~mL}$ of $0.2024 \mathrm{mg} / \mathrm{mL} ; 8: 0.7$ $\mathrm{ml}$ of $0.2126 \mathrm{mg} / \mathrm{mL}$ ), triethylamine ( $0.1 \mathrm{~mL}, 0.72 \mathrm{mmol}), 0.1$ $\mathrm{mL} ; 0.89 \mathrm{mmol}$ ) of yodobenzene, and $8 \mathrm{~mL}$ of DMF as solvent, at $140{ }^{\circ} \mathrm{C}$ with vigorous shaking for 30 minutes, then $(0.15 \mathrm{Ml}$; $1.3 \mathrm{mmol}$ ) of styrene was added maintaining the temperature and agitation.

The monitoring of the reaction was done by gas chromatography (GC) taking samples every hour, for 12 hours, also were taken two samples at 23 and 24 hours of reaction, adding $0.1 \mathrm{~mL} \mathrm{Et}_{3} \mathrm{~N}$ after each sample. Products obtained from the reaction were separate and characterize by GC coupled to masses.

2. In vitro biological activity of ligands and complexes against strain Aspergillus niger (A. niger)

For the evaluation of antifungal activity, the broth microdilution method was used, a standardized method recommended by the Clinical and Laboratory Standards Institute (CLSI) for the study of sensitivity to antifungals.

The procedure was done according to the recommendations of CLSI M38-A [9]. The strain used was supplied by laboratory of Department of Biology, Universidad del Valle. The microbiology group Universidad del Valle, leaded by Dr. Sci. Neyla Benitez, carried out the biological tests.
For fungal growth microdilution method was used in broth, using Mueller Hinton $(\mathrm{MH})$, the method further agar diffusion potato dextrose (PDA its acronym potato dextrose agar) was used, the means of culture were incubated at $35^{\circ} \mathrm{C}$ for 5 days.

To increase the concentration of conidia, this, were taken from a young A. Niger culture (5 days) and suspended in $1 \mathrm{~mL}$ of saline solution, agitated strongly, from this initial inoculum, a 10-1 dilution was prepared and this was the final inoculum for assay. The number of conidia was verify by the standard plate count method on PDA agar, obtaining a value of $1.15 \times 10^{5}$ spores $/ \mathrm{mL}$

Subsequently, the tests were carried out by the two methods mentioned, taking into account the protocol recommended by the CLSI, in both cases, the Mueller Hinton culture medium was used. The sample was diluted in $16,8,4,2,1,0.5,0.25$, $0.125,0.0625,0.03125 \mathrm{~g} / \mathrm{mL}$ for each of the compounds to be tested. Ketoconazole (positive control) was used at concentration of $16 \mu \mathrm{g} / \mathrm{mL}$ and as negative control strain $A$. Niger, without any test substance.

Microdilution plates were incubate at $35{ }^{\circ} \mathrm{C}$ for five days, after which time the result were analyze. It was observed, that with both methods the same result was obtained. Finally, the broth microdilution method was chosen since, it offers greater operation facilities during the assembly of the tests.

Additionally, tests were performed to verify if there was inhibition in the growth of A. Niger on PDA Agar plates.

\section{RESUlts AND DISCUSSION}

\section{A. Synthesis and characterization of benzotriazole ligands}

\section{Compound 1,3-phenylenebis((1H-benzotriazol-1-yl)me- thanone), (3):}

The synthesis of $\mathbf{3}$ was done by direct reaction of 1, 2 and $\mathrm{Et}_{3} \mathrm{~N}$ in toluene for 72 hours, Fig. 1.

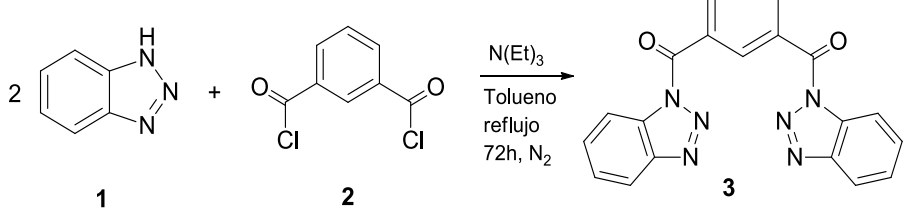

Fig 1. Synthesis of compound 3.

Ligand 3, was obtained as a white precipitate, stable to air, with a yield of $41.78 \%$ and a decomposition point of $184{ }^{\circ} \mathrm{C}$. The ligand was characterized by FT-IR, mass spectrometry, mono and two-dimensional NMR $\left({ }^{1} \mathrm{H},{ }^{13} \mathrm{C}\right.$, in $\left.\mathrm{CDCl}_{3}\right)$, assignments were corroborated using two-dimensional studies. The mass spectrum obtained by electronic impact, allowed to observe the expected molecular ion $\mathrm{m} / z 368[\mathrm{M}]^{+}$, Fig. 2. 


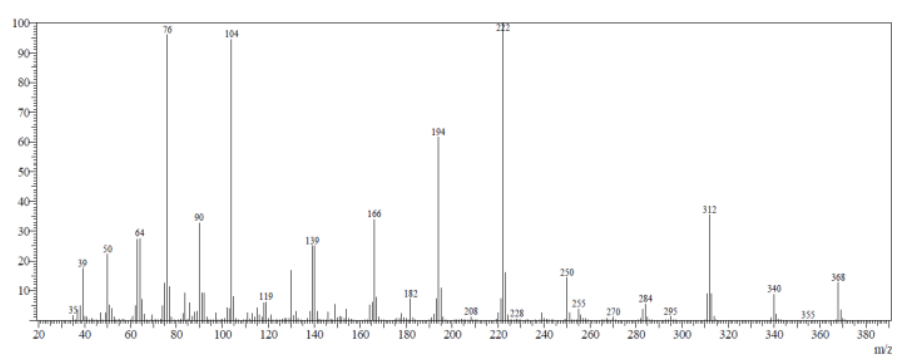

Fig. 2. Mass spectrum of compound 3.

The possible fragmentation mechanism for compound $\mathbf{3}$, presented in Fig. 3, allows to observe a base peak at $\mathrm{m} / \mathrm{z} 222$, which corresponds to $\alpha$-break characteristic of carbonyl group of the aromatic amides, also giving as a result a peak at $\mathrm{m} / \mathrm{z} 118$, which corresponds to benzotriazole. On the other hand, another possible route is the product of the $\alpha$-break and subsequent loss of $\mathrm{CO}$.

In addition, from the base peak, the subsequent rupture of the benzotriazole ring is generated, which has several characteristic breaks of $\mathrm{N}$-heterocyclic amides, such as, for example, proton transfer of the aromatic ring attached to the carbonyl group and subsequent loss of benzotriazole, which leads to the peak at $\mathrm{m} / \mathrm{z}$

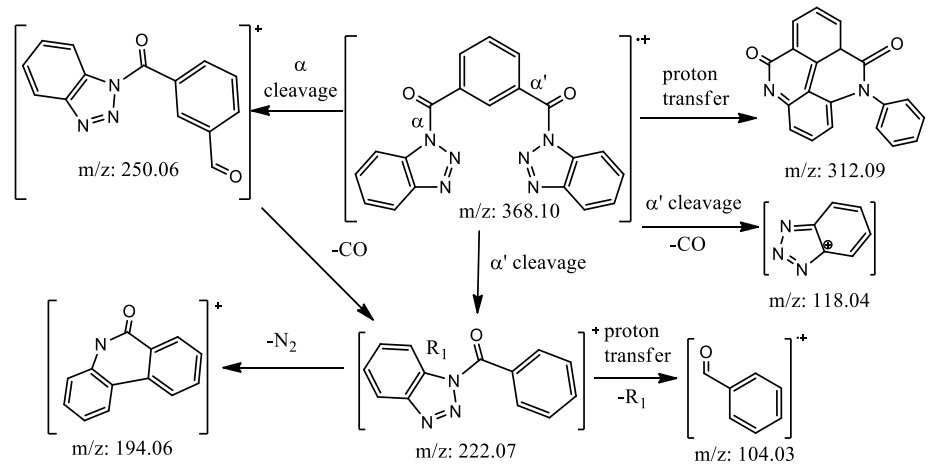

Fig. 3. Possible mechanism of mass fragmentation for compound $\mathbf{3}$. 104.

The analysis of the infrared (IR) spectrum of compound $\mathbf{3}$ shows that, in comparison of IR spectra of ligand with benzotriazole, the $v(\mathrm{~N}-\mathrm{H})$ characteristic band at $3400 \mathrm{~cm}-1$ of benzotriazole is absent. The characteristic band of carbonyls groups $v(\mathrm{C}=\mathrm{O})$ was observed at $1695.43 \mathrm{~cm}^{-1}$; the tension band of the $v(\mathrm{C}-\mathrm{N})$ bond appears at $1450.47 \mathrm{~cm}^{-1}$, related to the bond between benzotriazole molecules and the central ring of isophthaloyl.

Assignments for the characteristic bands of compound $\mathbf{3}$ are presented in table I.

TABLE I:

ASSIGNMENTS OF CHARACTERISTIC IR BANDS FOR LIGAND 3

\begin{tabular}{cl}
\hline \hline Band $\left(\mathbf{c m}^{-1}\right)$ & \multicolumn{1}{c}{ Assignment } \\
\hline 3082.25 & Asymmetric stretching C-H of the aromatic rings \\
1695.43 & Stretching of the carbonyls groups \\
1487.12 & Stretching C=C-C of the aromatic rings \\
1450.47 & Symmetric stretches of the C-N bond
\end{tabular}

1209.37 Flexion in the C-H bond plane

1039.63 Feature of benzotriazoles Symmetric stretching N-N

${ }^{1} \mathrm{H}$ NMR spectrum for ligand $\mathbf{3}$ with the signals assigned to each hydrogen and the numbering of the molecule is in Fig. 4.

The triplets at $7.61 \mathrm{ppm}(\mathrm{H}-9,2 \mathrm{H})$ and $7.78 \mathrm{ppm}(\mathrm{H}-8,2 \mathrm{H})$ with coupling constants $\mathbf{J}=7.8 \mathrm{~Hz}$ and $\mathbf{J}=7.7 \mathrm{~Hz}$ respectively,

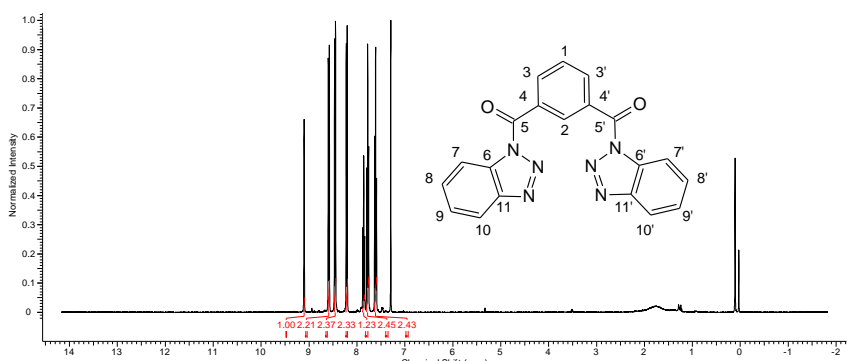

Fig. 4. Assignment shift chemical ${ }^{1} \mathrm{H}$ NMR and ${ }^{13} \mathrm{C}$ compound 3

the doublets at $8.21 \mathrm{ppm}(\mathrm{H}-7, \mathrm{~J}=8.2 \mathrm{~Hz})$ and $8.46 \mathrm{ppm}(\mathrm{H}-10$, $\mathrm{J}=8.2 \mathrm{~Hz}$ ) correspond to the hydrogens of the benzotriazole rings.

The signal at $7.86 \mathrm{ppm}$ belonging to $\mathrm{H}-1$ that integrates for $1 \mathrm{H}$, shows a triplet characteristic for hydrogen of this nature, with a coupling constant of $\mathrm{J}=7.9 \mathrm{~Hz}$, the doublet at $8.59 \mathrm{ppm}$, integrates for $2 \mathrm{H}$, corresponds to $\mathrm{H}-3$ and its coupling constant is $\mathrm{J}=8.2 \mathrm{~Hz}$, at $9.1 \mathrm{ppm}$. Is the singlet belonging to $\mathrm{H}-2$, signal that integrates for $1 \mathrm{H}$ (Fig. 5). It was noted that the presence or absence of this hydrogen in the spectra of the metal complexes is important because it allows corroborating whether or not there was metal-carbon bond formation.

All the data obtained corroborate with analysis of the twodimensional spectra and are consistent with the proposed formulation.

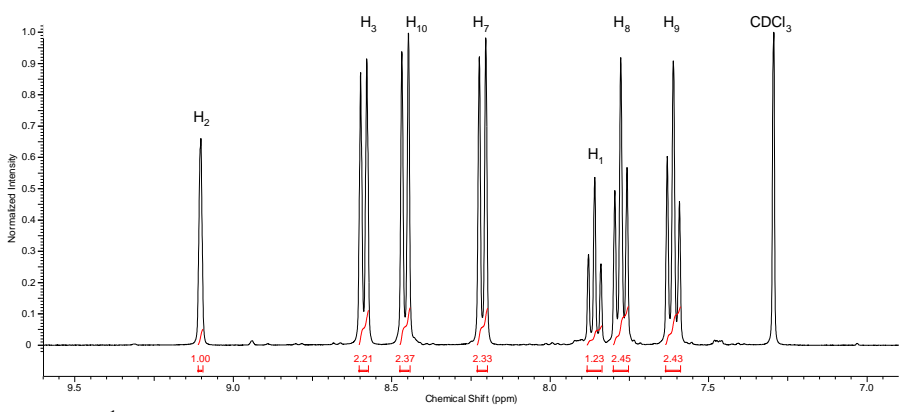

Fig. 5. ${ }^{1} \mathrm{H}$ NMR extended aromatic zone spectrum in $\mathrm{CDCl}_{3}$ for compound 3

Fig. 6 shows the ${ }^{13} \mathrm{C}$ NMR spectrum for compound $\mathbf{3}$, indicating the assignment of each signal to corresponding carbons. The signal at $165.56 \mathrm{ppm}$ belonging to C5 corresponds to quaternary carbons of the connecting carbonyls. The signals at $145.85,132.22$ and $132.05 \mathrm{ppm}$ correspond to quaternary carbons $\mathrm{C} 11, \mathrm{C} 4$ and $\mathrm{C} 6$ respectively. The signal at $135.02 \mathrm{ppm}$ was assigned to $\mathrm{C} 2(\mathrm{CH})$; it is an important assignment, because it will allow knowing whether there is an $\mathrm{M}-\mathrm{C}$ bond when reacting with a metallic center. The assignments were 
corroborate with the two-dimensional analysis and according to the proposal made.
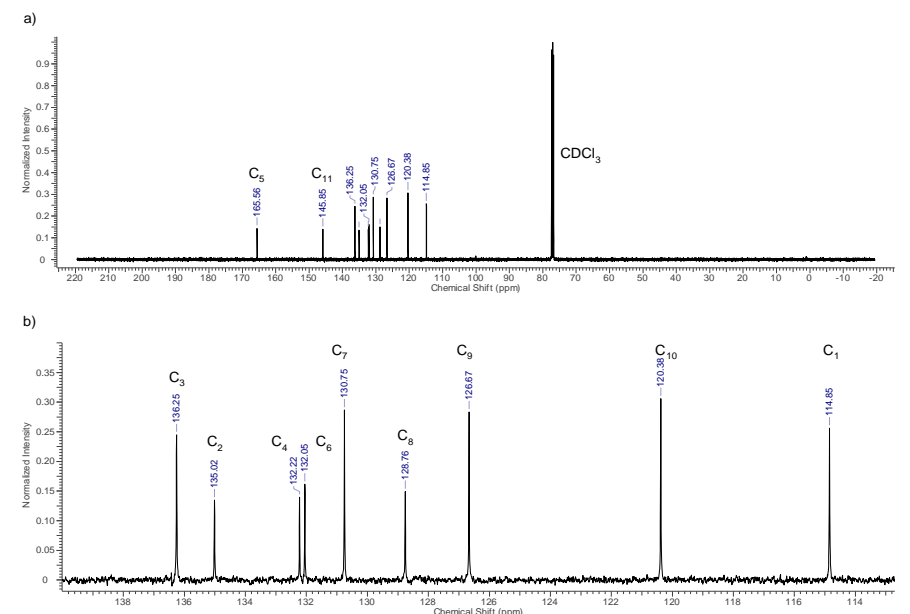

Fig. 6. ${ }^{13} \mathrm{C}$ NMR spectrum in $\mathrm{CDCl}_{3}$ for compound 3. a) Full spectrum, b) extended aromatic zone. (5):

Compound 1,3-bis(1H-benzotriazol-1-ylmethyl)benzene,

Ligand $\mathbf{5}$ was prepared by the direct reaction of the azole derivative $\mathbf{1}$ and the xylene chloride $\mathbf{4}$, in toluene with the presence of the base $\mathrm{Et}_{3} \mathrm{~N}$ for a period of 72 hours, Fig. 7. The product precipitates as a white solid, stable to air, with a yield of $53.08 \%$ and melting point at $138^{\circ} \mathrm{C}$.

The characterization of ligand $\mathbf{5}$ was carried out, by mass spectrometry and by FT-IR and NMR spectroscopy and is consistent with that reported in the literature [10-12].
2<smiles>c1ccc2[nH]nnc2c1</smiles>

1

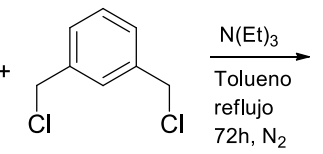

4

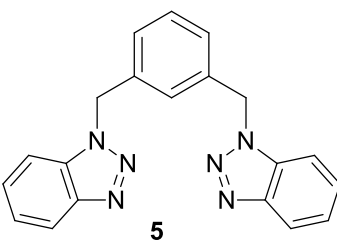

5
Fig. 7. Synthesis of compound 5

\section{B. Synthesis and characterization of complexes}

The pincer ligands can be coordinated to tridentate shaped metal center and generate very stable complexes with high yields. Protocols described in the literature have shown that it is possible to synthesize cyclametlated complexes of palladium (II) and nickel (II) using the same ligands, however, it has been shown that by the same synthetic routes it is possible to obtain complexes with the ligands acting with a Metal shape pincer and with the other as chelates.

\section{Compound $\quad[\operatorname{Pd}(\mathrm{NN}-(1,3-b i s((1 \mathrm{H}$-benzotriazol-1-ylme- thyl)benzene)) $\left.\mathrm{Cl}_{2}\right]$, (7):}

In this synthesis the ligand 3 reacted with $\left[\mathrm{PdCl}_{2}\left(\mathrm{CH}_{3} \mathrm{CN}\right)_{2}\right]$, 6 in THF at reflux for 16 h, as shown in Fig. 8. After filtering, washing and drying process, a brown solid was obtain, stable to air, with a yield of $36.33 \%$. The complex was characterize by FT-IR and NMR $\left({ }^{1} \mathrm{H},{ }^{13} \mathrm{C}\right)$, the assignments are corroborated with two-dimensional studies.

The comparison of the bands FT-IR of the complex 7 and ligand $\mathbf{3}$ show in Table II. It can be observed that the bands of the complex present a slight shift with respect to free ligand; these displacements are evidence of coordination of the ligand to the metallic center.

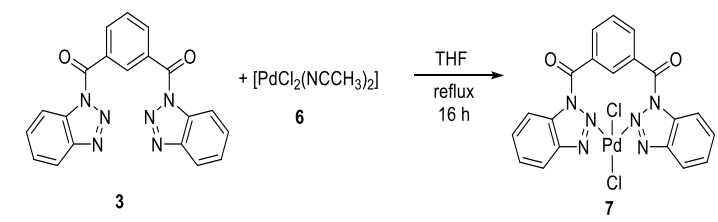

Fig. 8. Synthesis of compound 7

TABLE II.

AssignMENT Of TyPicAL FT-IR BANDS OF THE LIGAND 3 AND THE COMPLEX 7.

\begin{tabular}{ccc}
\hline \hline $\begin{array}{c}\text { Assignment of typical } \\
\text { FT-IR bands }\end{array}$ & Band $\left(\mathbf{c m}^{-1}\right) \mathbf{3}$ & Band $\left(\mathbf{c m}^{-\mathbf{1}}\right) \mathbf{7}$ \\
\hline $\mathrm{v}(\mathrm{C}-\mathrm{H})_{\text {aromatic }}$ & 3082.25 & - \\
$\mathrm{v}(\mathrm{C}=\mathrm{O})$ & 1695.43 & 1621.22 \\
$\mathrm{v}(\mathrm{C}=\mathrm{C}-\mathrm{C})_{\text {aromatic }}$ & 1487.12 & 1489.42 \\
$\mathrm{v}(\mathrm{C}-\mathrm{N})$ & 1450.47 & 1447.26 \\
$\delta(\mathrm{C}-\mathrm{H})$ & 1209.37 & 1213.37 \\
$\mathrm{v}(\mathrm{N}-\mathrm{N})_{\text {benzotriazole }}$ & 1039.63 & 1025.84 \\
\hline \hline
\end{tabular}

For complex 7 a very intense and wide band appears that extends from 3700 to $2400 \mathrm{~cm}^{-1}$, which is evidence of the complex hygroscopic nature, however, the band can be observed at $1213.37 \mathrm{~cm}^{-1}$, corresponding to the flexion of the aromatic ring and also observed as the band continues to appear related to the presence of the $\mathrm{C}-\mathrm{N}$ bond. Therefore, it was observe that the ligand is still having benzotriazole in its structure. In general, the coordination of the metallic center leads to a decrease in the energy of the vibrations, this serves as an indication to know that palladium stabilizes the ligand molecule.

Fig. 9, shows the ${ }^{1} \mathrm{H}-\mathrm{NMR}$ spectrum for complex 7. In this spectrum, a displacement the signals was observed, with respect to free ligand, caused by the coordination to palladium metal center. Obviously, being very clear that there was a change in the working solvent, for free ligand was $\mathrm{CDCl}_{3}$ and in this case it is DMSO- $\mathrm{d}_{6}$, however, as reported in the literature [13], the difference of chemical shifts generated by the change between these solvents is very low enough to avoid, that the comparison between both spectra can be made. Even, it was propose, that 
the concentration affects even more the chemical displacements

a)
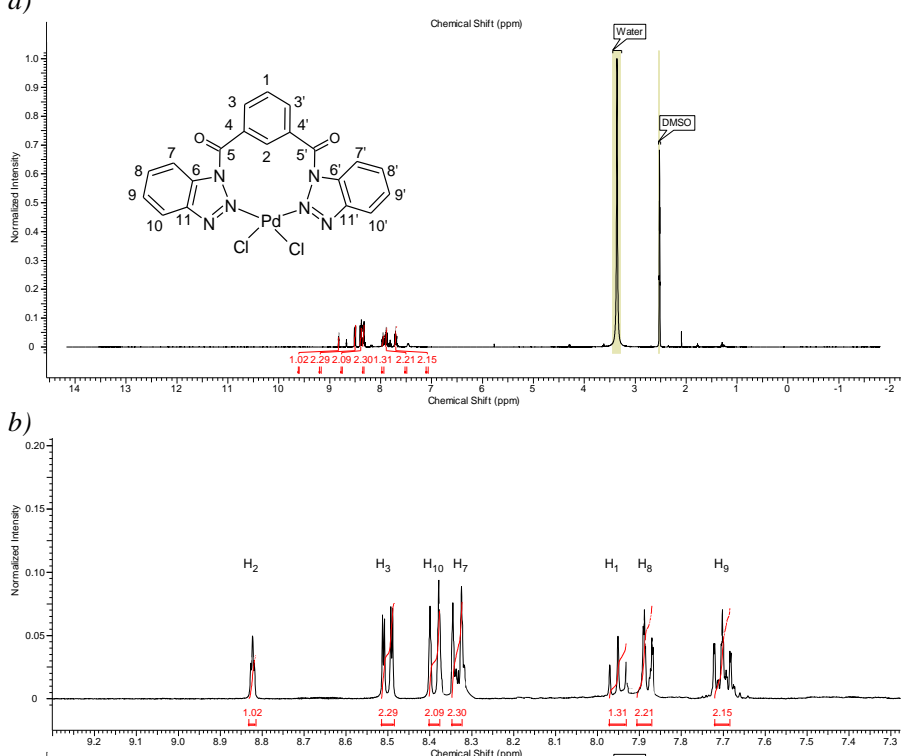

Fig. 9. ${ }^{1} \mathrm{H}$ NMR spectrum in DMSO-d $\mathrm{d}_{6}$ for complex 7. a) Full spectrum, b) extended aromatic zone.

than the working solvents [14-15].

The signal of the characteristic proton to identify the type of coordination, $\mathrm{H}-2$, appears at $8.82 \mathrm{ppm}$ as a singlet that integrates for $1 \mathrm{H}$, this is an evidence, that the coordination was of the $N-N$ type and not $N-C-N$, therefore, it is not a ligand that behaves like a pincer. The other signals have shifted slightly towards the lower field with respect to those of the free ligand, consequently of the coordination of the metallic center.

${ }^{13} \mathrm{C}$ NMR spectrum for complex 7 , a slight shift in the signals is observed with respect to ligand $\mathbf{3}$, however, nothing indicating a drastic change in the environment of the carbon nuclei, the signals that appear in the spectrum correspond as follows: $166.23 \mathrm{ppm}$ (quaternary carbon, C5), $145.77 \mathrm{ppm}$ (quaternary carbon, C11), 132.19 ppm (CH, C3), 134.18 ppm (CH, C2), 132.38 ppm (quaternary carbon, C4), 132.19 ppm (quaternary carbon, C6), $131.44 \mathrm{ppm}(\mathrm{CH}, \mathrm{C} 7), 127.34 \mathrm{ppm}$ $(\mathrm{CH}, \mathrm{C} 8), 124.89 \mathrm{ppm}(\mathrm{CH}, \mathrm{C} 9), 120.63 \mathrm{ppm}(\mathrm{CH}, \mathrm{C} 10)$, $115.01(\mathrm{CH}, \mathrm{C} 1)$.

These assignments were perform with support of the twodimensional experiment DEPT 135, which showed the signal corresponding to $\mathrm{C} 2$, indicates that there was no $\mathrm{M}-\mathrm{C}$ coordination and therefore, the ligand is not a pincer type.

The NMR spectra showed a decrease in the intensity of the signals because of the change in the chemical environment of the complex molecule, the metallic center affects the resonance effect of the organic nuclei.

Compound $\quad[\operatorname{Pd}(N N-(1,3-b i s((1 H$-benzotriazole-1-ylmethyl)benzene) $\left.) \mathrm{Cl}_{2}\right],(8)$ :

In this synthesis, ligand $\mathbf{5}$ was reacted with $\left[\mathrm{PdCl}_{2}\left(\mathrm{CH}_{3} \mathrm{CN}\right)_{2}\right], \mathbf{6}$ in acetonitrile under reflux for $15 \mathrm{~h}$, Fig.
10 After the filtering, washing and drying process, was obtain a yellow-brown solid, stable to the air, with a yield of $85 \%$.

Complex 8, was characterize by FT-IR and NMR $\left({ }^{1} \mathrm{H},{ }^{13} \mathrm{C}\right)$, assignments were corroborate with two-dimensional studies.

Parallel of FT-IR bands for complex $\mathbf{8}$ and ligand $\mathbf{5}$ are show in Table III.

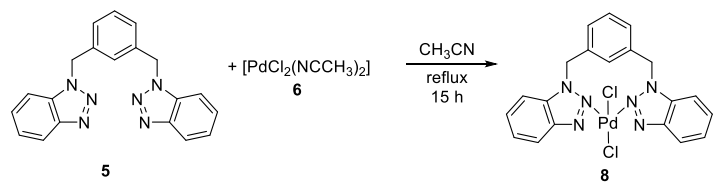

Fig. 10. Synthesis of compound $\mathbf{8}$

TABLE III.

ASSIGNMENT OF TYPICAL FT-IR BANDS OF LIGAND 5 AND COMPLEX 8.

\begin{tabular}{ccc}
\hline \hline $\begin{array}{c}\text { Assignment of typical } \\
\text { FT-IR bands }\end{array}$ & Band $\left(\mathbf{c m}^{-\mathbf{1}}\right) \mathbf{5}$ & Band $\left(\mathbf{c m}^{-\mathbf{1}}\right) \mathbf{8}$ \\
\hline $\mathrm{v}(\mathrm{C}-\mathrm{H})$ phenyl $(\mathrm{Ph})$ & 3057.17 & 3062.96 \\
$\mathrm{v}\left(\mathrm{CH}_{2}\right)_{\text {as }}$ & 2980.02 & 2960.73 \\
$\mathrm{v}(\mathrm{C}=\mathrm{C}-\mathrm{C})_{\text {aromatic }}$ & 1492.90 & 1492.90 \\
$\mathrm{v}(\mathrm{C}-\mathrm{N})$ & 1452.40 & 1454.33 \\
$\mathrm{v}(\mathrm{N}-\mathrm{N})_{\text {benzotriazole }}$ & 1078.21 & 1001.06 \\
\hline \hline
\end{tabular}

Based on the above, the bands show a slight displacement, with exception of the characteristic band of the $N-N$ symmetric stretch in benzotriazole of ligand that pronounced towards $1078.21 \mathrm{~cm}^{-1}$. This can be associated with the coordination of ligand to the metallic center of palladium through the nitrogenous part of ligand. This behavior is much more marked for this complex 8 than for $\mathbf{7}$, where the shift of this band was much lower.

The signals of the ${ }^{1} \mathrm{H}$ NMR spectrum of the complex 8 , obtained in DMSO- $\mathrm{d}_{6}$ show in Table IV and assigned with respect to Fig. 11. A displacement of the signals, was observe due to coordination to the metallic center.

TABLE IV.

COMPARISON OF ${ }^{1} \mathrm{H}$ NMR SignAls COMPLEXES 7 AND 8.

\begin{tabular}{c|cc}
\hline \hline $\begin{array}{c}\text { Assignment of } \\
\text { typical proton }\end{array}$ & $\begin{array}{c}\text { Shift } \boldsymbol{\delta}(\mathbf{p p m}) \\
\text { complex 7 }\end{array}$ & $\begin{array}{c}\text { Shift } \boldsymbol{\delta}(\mathbf{p p m}) \\
\text { complex 8 }\end{array}$ \\
\hline H-2 & $1 \mathrm{H}, \mathrm{s}, 7.33$ & $1 \mathrm{H}, \mathrm{s}, 7.32$ \\
H-3 & $2 \mathrm{H}, \mathrm{d}, 7.37$ & $2 \mathrm{H}, \mathrm{d}, 7.27$ \\
H-1 & $1 \mathrm{H}, \mathrm{s} . \mathrm{a} .7 .40$ & $3 \mathrm{H}, \mathrm{t} .7 .40$ \\
H-5 & $4 \mathrm{H}, \mathrm{s}, 5.98$ & $4 \mathrm{H}, \mathrm{s}, 5.48$ \\
H-7 & $2 \mathrm{H}, \mathrm{d}, 7.62$ & $2 \mathrm{H}, \mathrm{d}, 7.74$ \\
H-8 & $2 \mathrm{H}, \mathrm{d} . \mathrm{a} .7 .47$ & $3 \mathrm{H}, \mathrm{t}, 7.40$ \\
H-9 & $2 \mathrm{H}, \mathrm{d} . \mathrm{a} .7 .43$ & $2 \mathrm{H}, \mathrm{t}, 7.48$ \\
$\mathrm{H}-10$ & $2 \mathrm{H}, \mathrm{d}, 8.03$ & $2 \mathrm{H}, \mathrm{d}, 8.05$ \\
\hline \hline
\end{tabular}




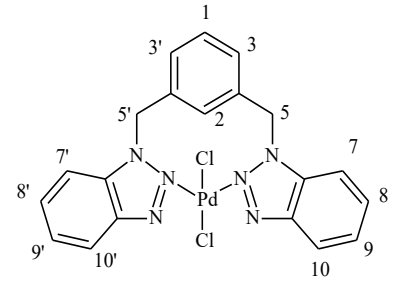

Fig. 11. Structure of complex 8 to assign the signals of the ${ }^{1} \mathrm{H}$ and ${ }^{13} \mathrm{C}$ NMR spectra.

Complex $\mathbf{8}$ the presence of $\mathrm{H}-2$ at 7.32 ppm appears as a singlet, so that ligand $\mathbf{5}$ also did not act as a pincer. The methylene groups that are connectors between the central aromatic ring and benzotriazole appear at $5.96 \mathrm{ppm}$ as a singlet that integrates for $4 \mathrm{H}$. The spectroscopic profile was not observe of an $\mathrm{AB}$ system, since the characteristic signals were maintain of ligand $\mathbf{5}$, indicating that there was no greater change in the environments of the protons of free ligand compared with those of complex. Neither, presence of another isomer was observed; which rules out that there is a rearrangement in benzotriazole ring. $\mathrm{H}-3$ protons of the central aromatic ring appear as a doublet at $7.27 \mathrm{ppm}(\mathrm{J}=7.2 \mathrm{~Hz})$, proton related to $\mathrm{H}-1$ appears together with $\mathrm{H}-8$ protons, showing a very similar chemical nature.

The table below (Table V) shows a comparison of ${ }^{13} \mathrm{C} \mathrm{NMR}$ signals for complexes $\mathbf{7}$ and $\mathbf{8}$.

TABLE V.

COMPARISON OF ${ }^{13} \mathrm{C}$ NMR SIGNALS COMPLEXES 7 AND 8.

\begin{tabular}{ccc}
\hline \hline $\begin{array}{c}\text { Assignment of } \\
\text { typical carbon }\end{array}$ & Shift $\mathbf{\delta}(\mathbf{p p m}) \mathbf{7}$ & Shift $\boldsymbol{\delta}(\mathbf{p p m}) \mathbf{8}$ \\
\hline $\mathrm{CH}_{2}$ & 51.16 & 51.23 \\
$\mathrm{C}-6$ & 132.90 & 133.08 \\
$\mathrm{C}-4$ & 136.75 & 136.95 \\
$\mathrm{C}-11$ & 146.14 & 145.76 \\
$\mathrm{C}-2$ & 129.44 & 129.36 \\
$\mathrm{C}-9$ & 127.60 & 128.04 \\
$\mathrm{C}-3$ & 127.23 & 127.93 \\
$\mathrm{C}-1$ & 126.32 & 127.72 \\
$\mathrm{C}-8$ & 123.74 & 124.50 \\
$\mathrm{C}-7$ & 119.47 & 119.69 \\
$\mathrm{C}-10$ & 110.19 & 111.05 \\
\hline \hline
\end{tabular}

Assignment of quaternary carbons to $145.76 \mathrm{ppm}$ (C-11), $136.95 \mathrm{ppm}(\mathrm{C}-4)$ and $133.08 \mathrm{ppm}$ (C-6), was done with the support of the two-dimensional experiment DEPT 135.

The C-2 signal observed at $129.86 \mathrm{ppm}$, an important signal, indicates that, there is not $\mathrm{M}-\mathrm{C}$ bond, and it is consistent with ${ }^{1} \mathrm{H}-\mathrm{NMR}$ spectrum, from which it is concluded that coordination with metallic center was bidentate $N-N$, that is, ligand $\mathbf{5}$ acts as a chelate and not as a pincer in its coordination to complex 8 .

In the range of 111.05 to $128.04 \mathrm{ppm}$, signals for other tertiary carbons are observed. The signal at $51.23 \mathrm{ppm}$ corresponds to C5, of methylene groups.
For both ligands and complexes observed a very similar behavior, in its spectroscopy, this was expected by the similarity of both compounds, however, the presence of the carbonyl groups that behave as electroatractors, makes the signals of $\mathbf{3}$ and $\mathbf{5}$ appear to field lower than for their counterparts 7 and $\mathbf{8}$. It wait that the carbonyl effect will also generate differences in the catalytic behavior of both compounds.

\section{Preliminary catalytic activity}

The Mizoroki-Heck preliminar catalytic activity of compounds $\mathbf{7}$ and $\mathbf{8}$ were observe using as substrates styrene and yodobenzene. Fig. 12, shows a schematic description of the reaction.
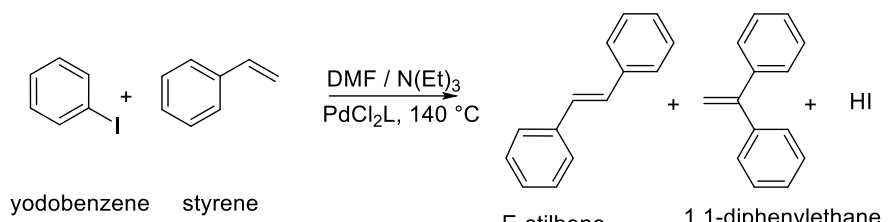

Fig. 12. Mizoroki-Heck reaction between yodobenzene and styrene

The reaction was carried out using as catalyst palladium complexes of the type $\mathrm{PdCl}_{2} \mathrm{~L}(\mathrm{~L}=7$ or 8$)$ in a relation catalyst: substrate 1:3000. Catalyst 7 obtained a $91.59 \%$ of conversion respect to yodobenzene and a $80.72 \%$ of selectivity toward $E$ stilbene, after $24 \mathrm{~h}$ of reaction (TON 221). Conversion of yodobenzene using complex $\mathbf{8}$, was $97.19 \%$ and selectivity to $E$-stilbene is $85.87 \%$ after 24 h of reaction (TON 219). This results show that both catalyst are regioselective towards $E$ stilbene, keeping a selectivity in $80-85 \%$ during the reaction. After $1 \mathrm{~h}$ of reaction, was observed a higher conversion of yodobenzene in the reaction catalyzed by $7,84.62 \%$, versus $60.98 \%$ converted by $\mathbf{8}$, this values are in the average for similar compounds [8], in turn, the percentage of selectivity of each species produced is also affected by the difference in the ligands of each catalyst. The catalytic precursor of type 7 offers a selectivity towards E-stilbene of $85.03 \%$ and of $14.97 \%$ towards 1,1-diphenylethene, while complex $\mathbf{8}$ is selective in $53.51 \%$ and $36.49 \%$ towards E-stilbene and 1,1diphenylethene, respectively.

\section{In vitro antifungal activity}

In vitro antifungal activities of synthesized ligands $(\mathbf{3}, \mathbf{5})$ and complexes $(\mathbf{7}, \mathbf{8})$ were carried out using the broth microdilution method, recommended by the CLSI, and the diffusion method in potato and dextrose agar (PDA) was used to verify the presence of the fungus $A$. niger and compared with standard antifungal drug Ketoconazole at the same concentration.

This activity was evaluated in a range of 0.03125 to 16 $\mu \mathrm{g} / \mathrm{mL}$ using solvent DMSO: RPMI Broth (1:50) for compounds. As a negative control, the inoculum of $A$. niger, without any test substance. Each culture medium was incubated at $35^{\circ} \mathrm{C}$ for a period of 5 days. 
After the incubation period, the results indicate that A. niger is resistant, because, it was presence of the fungus in each well of the trial, which verified by growth of the study fungus on PDA agar plates. Free ligands the palladium complexes did not show antifungal activity in the range of concentrations used against $A$. niger.

The inactivity of the compounds may be due to the compounds are dissociated, that is, they are not stable under intracellular physiological conditions. Another reason is that the compounds are not soluble in intracellular or extracellular conditions, considering the levels of acidity that the organism can generate with its excretions. In the case of metal complexes, it may be due to their low lipophilicity.

The above situations indicate estimation of aqueous speciation of the complexes can be by finding the hydrolysis constants of the metals $\left(\mathrm{K}_{\mathrm{h}}\right)$, the constants of acidity $\left(\mathrm{K}_{\mathrm{a}}\right)$ of the ligands and the affinity constants $(\log \beta)$. With data you can simulate the species along the $\mathrm{pH}$ range and produce a graph of relative distribution, if it, do not can find Ka for the ligands, you could do a simulation with similar ligands and their respective values, thus having a way of predicting how stable the complexes are under cellular conditions.

The compounds derived from benzotriazole and with great steric hindrance evidence low antifungal activity against $C$. albicans [16], it can be due to low penetration capacity in the cells. Biological activity of compounds also depends on the nature of ligand, concentration, nature of metal ion, nature of anion surrounding the metal ion, coordinating sites and geometry of complexes.

\section{CONCLUSION}

New, air-stable Pd (II) complexes, containing bidentate $N N$ donor ligands, were synthesized and characterized. The structures of the ligands: 1,3-bis $((1 H$-benzotriazol-1-yl $)$ methyl) benzene and 1,3-bis(1H-benzotriazol-1-yl) methanone) benzene were characterized spectroscopically.

The coordination ligands $(3,5)$ with Pd (II) metallic center was bidentate $\mathrm{N}-\mathrm{N}$ and is not a pincer ligand.

Synthesized palladium complexes were highly active as catalysts in the Mizoroki-Heck reaction involving yodobenzene and styrene as substrates: great selectivity towards the production of $E$-stilbene was evidenced.

The results of antifungal activity for the free ligands and their metal complexes with Pd (II) rule out activity against the specie of Aspergillus studied with the conditions of solubility present for complexes and ligands.

\section{ACKNOWLEDGMENT}

Thanks to the vice-chancellor Research of the Universidad del Valle for the financial support. Also thanks Department of Chemistry and the Faculty of Natural and Exact Sciences of the Universidad del Valle, for the academic support.

Thanks Department of Biology, Universidad del Valle. The microbiology group Universidad del Valle, leaded by Dr. Sci. Neyla Benitez for technical support in the strain y biological activity.

Thanks researcher Farrah Cañavera Buelvas of the Chemistry Departament, Universidad del Atlántico for academic support and direction in the thesis of Carolina student.

\section{REFERENCES}

[1] R. Contreras, A. Flores-Parra, E. Mijangos, F. Téllez, H. LópezSandoval, N- Barba-Behrens, "From mono to polydentate azole and benzazole derivatives, versatile ligands for main group and transition metal atoms" Coord. Chem. Rev., vol. 253, no. 15, pp. 1979-1999, Ago. 2009. doi: 10.1016/j.ccr.2009.02.020

[2] T. J. P. McGivern, S. Afsharpour, C. J. Marmion, "Copper complexes as artificial DNA metallonucleases: from Sigman's reagent to next generation anti-cancer agents?" Inorg. Chim. Acta, vol. 472, no. 1, pp. 12-39. Mar. 2018. doi: 10.1016/j.ica.2017.08.043

[3] R. G. Pearson, "Hard and soft acid bases" J. Am Chem. Soc., vol. 85, no. 22, pp. 3533-3539. Nov. 1963.

[4] R. J. Sundberg, R. B. Martin, "Interactions of histidine and other imidazole derivatives with transition metal ions in chemical and biological systems" Chem. Rev., vol. 74, no. 4, pp. 471-517, Ago. 1974.

[5] D. Reddy, K. J. Akerman, M. P. Akerman, D. Jagany, “A kinetic investigation into the rate of chloride substitution from chloro terpyridine platinum (II) and analogous complexes by a series of azole nucleophiles" Transition Met. Chem., vol. 36, no. 6, pp. 593602, Sep. 2011. doi: 10.1007/s11243-011-9507-x

[6] B. Barszcz, M. Gabryszewski, J. Kuligi, B. Lenarcik, "Potentiometric studies on complexes of silver (I) solutions. Part 2: Correlation between the solubility of the silver (I)-azole complexes and the ligand basicity," J. Chem. Soc., Dalton Trans., vol. 10, no. 10, pp. 2025-2028, Oct. 1986.

[7] I. S. Dogan, S. Sarac, S. Sari, D, Kart, S. E. Gokhan, M. Vural, S. Dalkara, "New azole derivatives showing antimicrobial effects and their mechanism of antifungal activity by molecular modeling studies" Eur. J. Med. Chem., vol. 130, no. 21, pp. 124-138, Abr. 2017. doi: 10.1016/j.ejmech.2017.02.035

[8] J. L Pratihar, P. Mandal, C. H. Lin, C. K. Lai, D. Mal, “Azo amida palladium (II) complexes: synthesis, characterization and application in C-C cross-coupling reactions". Polyhedron, vol. 135, pp. 224-230, Oct. 2017. doi: 10.1016/j.poly.2017.06.055

[9] National Committee for Clinical Laboratory Standards, Reference method for broth dilution antifungal susceptibility testing of filamentous fungi. Approved standard (NCCLS document M38-A), Clinical and Laboratory Standards Institute, Villanova, 2002.

[10] N. J. Bello, H. F. Pastrana, M. F. Garavito, A.G. Ávila, A. M. Celis, A. M. Castro, S. Restrepo and J. J. Hurtado, "Antibacterial Activities of Azole Complexes Combined with Silver 
Nanoparticles". Molecules, vol. 23, no. 2, pp. 361, Nov. 2018. doi: $10.3390 /$ molecules 23020361

[11] D. Fonseca, C. Páez, L. Ibarra, P. García, M. A. Macías, O. Triana and J. J. Hurtado, "Metal complex derivatives of bis(pyrazol-1yl)methane ligands: synthesis, characterization and antiTrypanosoma cruzi activity”. Transit. Met. Chem., pp. 1-10, Nov. 2018. doi: 10.1007/s11243-018-0277-6

[12] M. A. Macías, N. Nuñez, J. J. Hurtado and L. Suescun, "Crystal structure of 1,3-bis(1H-benzotriazol-1-ylmethyl) benzene". Acta Cryst., vol. E72, pp. 815-818, Nov. 2018. doi: $10.1107 /$ S2056989016007805

[13] S. Molchanov and A. Gryff, "Solvation of amides in DMSO and $\mathrm{CDCl}_{3}$ : An attempt at quantitative DFT-Based interpretation of ${ }^{1} \mathrm{H}$ and ${ }^{13} \mathrm{C}$ NMR chemical shifts". J. Phys. Chem., vol. A(121), pp. 9645-9653, Nov. 2017. doi: 10.1021/acs.jpca.7b10110

[14] H. Suhr, "Solvent effects on the nuclear magnetic resonance spectra of aromatic amines". Mol. Phys., vol. 6, pp. 153-155. Nov. 2017. doi: 1002/jhet.5570120304
[15] J. H. Looker, W. Mader and C. A. Kingsbury, "Solvent shifts in the NMR spectra of monomethoxy flavones a comparasion of four solvents systems". J. Heterocycl. Chem., vol. 12, pp. 467-470. Nov. 2017.

[16] Z. Rezaei, S. Khabnadideh, K. Pakshir, Z. Hossaini, F. Amiri and E. Assadpour, "Design, synthesis, and antifungal activity of triazole and benzotriazole derivatives". Eur. J. Med. Chem., vol. 44, no. 7, pp. 3064-3067, Nov. 2017. doi: 10.1016/j.ejmech.2008.07.012 